Agro-Science Journal of Tropical Agriculture, Food, Environment and Extension Volume 11 Number 3 September 2012 pp 1-11

ISSN IIIY-7455

\title{
EFFECTS OF AGRICULTURAL WASTES ASH ON NUTRIENTS CONCENTRATION AND YIELD OF MAIZE (Zea mays L) IN HAPLIC ACRISOL OF SOUTHEASTERN NIGERIA
}

\author{
Onwuka, M. I. and Osodeke, V.E. \\ Department of Soil Science and Meteorology, Michael Okpara University of Agriculture \\ Umudike, PMB 7267, Umuahia, Abia State, Nigeria \\ Correspondence email: ifyonwuka2000@yahoo.com or onwuka.ifeoma@ mouau.edu.ng
}

\begin{abstract}
Field trials and a pot experiment were conducted during the 2005 and 2006 cropping seasons at Michael Okpara University of Agriculture, Umudike, Nigeria, to assess the effect of various agricultural wastes ash on nutrient concentration, growth and yield of maize in a Haplic Acrisol. The treatments comprised palm bunch ash, kitchen residues ash, cocoa pod husk ash, saw dust ash, calcium carbonate, oyster shell ash and a control. Each of the ash was applied at five levels: 0, 2, 4, 6 and 8 tonnes per hectare. They were replicated three times in a split plot completely randomized design for the pot experiment and randomized completely block design for the field trials. The effects of the treatments were measured on nitrogen, phosphorus, potassium, calcium, and manganese and iron concentration in maize crop. Other plant parameters measured were maize height at 8 weeks after planting, stem diameter, stover weight and grain yield weight in the field trails. The results obtained showed that all the agricultural wastes significantly $(P<0.05)$ increased the concentrations of nitrogen, phosphorus, potassium and calcium. They also significantly $(p<0.05)$ reduced the concentration of iron and manganese in the plant. The wastes applied significantly increased the plant height at 8 WAP, maize stem diameter, stover weight and grain yield. Among the treatments tested, 6 t/ha of cocoa pod husk ash significantly $(P<0.05)$ increased nitrogen concentration in the maize from 0.49 in the control to 5.17\%. Plant height, stem diameter and stover weight were also increased by the application of 6t/ha of cocoa pod husk ash. While 4t/ha of kitchen residue ash, $4 t / h a$ of oyster shell ash and 4 t/ha of cocoa pod husk ash significantly $(P<0.05)$ increased the concentration of phosphorus from $1.01 \%$ to $4.98 \%$, calcium from $0.4 \%$ to $6 \%$ and potassium from $0.19 \%$ to $0.42 \%$ respectively. The soil $\mathrm{pH}$ correlated negatively with iron and manganese concentration, positively with phosphorus and calcium concentration. These results show that maize can be grown successfully on Haplic Acrisol of the Southeastern Nigeria using waste from agricultural products.
\end{abstract}

Key words: Agricultural wastes ash, nutrient concentration, growth, grain yield, Haplic Acrisol

\section{INTRODUCTION}

Among the cereal crops in subSahara Africa, maize (Zea mays L.) is the most important. This is because it generally adapts to all agro-ecological zones of the sub- Saharan Africa and it is high -yielding, easy to process and costs less than other cereals (Akinbola et al., 2009). Demand for maize in developing countries is projected to surpass both wheat and rice by 2020 (Akinbola et al., 2009). If care is not taken, this may not be actualized, and this is because in 2003, the projected output for maize production in Nigeria was 9.88 million metric tonnes, but the actual output realized was 7.02 million metric tonnes (Eleweanya, et al., 2005); a reduction of the expected output by 2.84 million metric tonnes.

One of the major problems causing the reduction in maize production is soil acidity. This is a major soil -related constraint to food production in Nigeria especially in the southeastern area (Asawalam and Onyegbule, 2009). The area receives > $2000 \mathrm{~mm}$ annual precipitation (Nwosu and Chukwu, 2009) and this leads to leaching of soil nutrients especially the basic cations leaving the soil with the acidic cations. These acidic cations principally those of aluminum and iron reduce the availability of phosphorus by forming insoluble compounds of $\mathrm{Al}$ and $\mathrm{Fe}$ oxides at $\mathrm{pH}$ less than 5.5 (Ahn, 
1993). Soils having low pH usually have low nutrient status, nutrient imbalance and multiple nutrient element deficiencies (Sanchez et al., 1983).

Achieving food security for the rapidly expanding population in Nigeria means intensifying food production on existing cropland through enhanced nutrient input and recycling. This recycling involves efficient utilization of the agricultural wastes to improve soil fertility and also create healthy environment that is devoid of these wastes which sometimes are detrimental to the health of the people.

Incinerating these agricultural wastes is one way of recycling them. Ash from agricultural wastes has been found to neutralize the acidity of the soil, improve soil nutrients and provide an enabling environment for beneficial soil micro- organisms to thrive (Lee et al; 2007). With the high cost of commercial liming material, smallholder farmers are finding it extremely difficult to acquire them. The ash from these agricultural wastes could be a better alternative to solving the problem of acidity in the region in order to increase maize production for the increasing population. Researchers like Nwite et al., (2011) and Nottidge, et al., (2007) who worked with different sources of ash in the Southeastern Nigeria, found that application of ash increased the rice and maize grain yield using leaf ash and wood ash respectively.

The objective of this study was to investigate the effect of ash from agricultural wastes on nutrient concentration and the yield of maize in a Haplic Acrisol of Southeastern Nigeria.

\section{MATERIALS AND METHOD}

This work was carried out at the experimental farm and greenhouse of Michael Okpara University of Agriculture Umudike ( $05^{\circ}$ $29^{`} \mathrm{~N}, 07^{\circ} 33^{`} \mathrm{E} ; 122 \mathrm{~m}$ above sea level) in the 2005 and 2006 planting seasons.

\section{Climatic condition of the experimental site}

The climate of Umudike is essentially humid rainforest; with a mean rainfall of 2200 $\mathrm{mm}$ per annum distributed over eight months (March- November). It has a bimodal rainfall peak in July and September with a short dry season spell in August popularly called August break. The monthly minimum air temperature ranges from $20^{\circ} \mathrm{C}$ to $24^{\circ} \mathrm{C}$ while the monthly maximum air temperature ranges from $28^{\circ} \mathrm{C}$ to $35^{\circ} \mathrm{C}$. The relative humidity varies from $51 \%$ to $87 \%$. The average sunshine hours vary from 3 to 7 hours and it appears to be lowest in the months of July, August and September but always highest in May. (NRCRI Umudike Meteorological Station 2007).

\section{The experimental site}

The soil of the experimental site has a sandy loam texture; the pH was 5.20 in 2005 and 5.39 in 2006 planting season. The soil organic carbon was 0.19 and $0.30 \%$ in 2005 and 2006, respectively while available phosphorus and total nitrogen were $3.90 \mathrm{mg} \mathrm{kg}^{-1}$ and $0.09 \%$ in 2005. In 2006 the initial soil available phosphorus and nitrogen were $9.90 \mathrm{mg} \mathrm{kg}^{-1}$ and $0.10 \%$. Exchangeable calcium was $1.02 \mathrm{cmol} \mathrm{kg}^{-}$ 1 (2005 planting season) and $1.98 \mathrm{cmol} \mathrm{kg}^{-1}$ (2006 planting season) while exchangeable potassium were 0.09 and $0.13 \mathrm{cmol} \mathrm{kg}^{-1}$ in 2005 and 2006 planting seasons respectively. The exchangeable magnesium was 0.20 and 0.52 cmol kg-1 in 2005 and 2006 planting seasons, respectively

\section{Cropping history of the experimental site,} pre-planting operations and soil sampling

Two different sites in the same location were used for the field trials in 2005 and 2006 planting seasons. In 2003 and 2004 cassava was planted in the first and second year trial fields respectively and was harvested in 2004 and 2005 in that order. After the harvest of the cassava, the lands were left fallowed for three months and the area was dominated by Mimosa pundica and Panicum maximum. The reason why the trails were carried out at same location but different sites was to remove the contribution of the residual effect of the applied treatments on the second planting. The fields were slashed, ploughed and beds manually made.

The soil for the greenhouse experiment was a composite of soil samples collected from the two sites where the field experiments were sited at Michael Okpara University of Agriculture Eastern Farms. The soils were collected from the depth of $0-15 \mathrm{~cm}$; air dried and passes through $5 \mathrm{~mm}$ sieve.

\section{Treatments and the test crop}

Treatments consisted of six liming materials with five rates. The materials were: cocoa pod husk ash (CHPA), oyster shell ash (OSA), palm bunch ash (PBA), calcium carbonate $\left(\mathrm{CaCO}_{3}\right)$, kitchen residues ash (KRA) and saw dust ash (SDA). The kitchen residues ash was generated from the fire place of the rural women. The rates of application of the various ashes were: $0,2,4$, 6 and 8 tonnes per hectare while the test crop was maize (Oba super-2 variety).

\section{Experiment 1: Greenhouse experiment}

The objective of the pot experiment was to determine the interaction of the liming materials and their application rates on nutrients concentration in maize. 
Ten kilogram of the air - dried composite samples was weighed, placed into 12- liter plastic buckets. Treatments were and laid out in a split plot design in a completely randomized design. Treatments were applied seven days before planting on air-dry weight basis and were replicated three times to give a total of ninety buckets. The kilogram's equivalent, of the rates used were $0.057 \mathrm{~kg}$ for 2 tonnes per hectare, $0.114 \mathrm{~kg}$ for 4 tonnes per hectare, $0.171 \mathrm{~kg}$ for 6 tonnes per hectare and $0.228 \mathrm{~kg}$ for 8 tonnes per hectare. Two seeds of the test crop were planted per pot and later thinned down to one plant per pot. The nutrient concentrations in the plants were determined at 8 weeks after planting. Wet oxidation method was used to digest the plant materials using Perchloric acid, $\mathrm{HNO}_{3}$ and $\mathrm{H}_{2} \mathrm{SO}_{4}$ (AOAC 1984). The $\mathrm{P}$ content of the samples was determined using the Vanadomolybdate yellow method and read using Spectrophotometer (UV-2400PC) at $420 \mathrm{~nm}$ while $\mathrm{Mn}, \mathrm{Fe}, \mathrm{Ca}$ and $\mathrm{K}$ filtrate were determined using AAS.

\section{Experiment 2: Field Trials in 2005 and 2006 early planting season}

The objective of the field trial was to determine the effect of the treatments on maize yield parameters and to verify the results obtained in the greenhouse.

A total land area of $111 \mathrm{~m}$ by $20 \mathrm{~m}$ $\left(2220 \mathrm{~m}^{2}\right)$ was marked out for the 2005 and 2006 field trials. The experiments were laid out in a split plot design in Randomized complete block design (RCBD). There were three replicates and the different liming materials occupied the main plots while the rates were assigned to the sub plots. Each main plot measured $17.5 \mathrm{~m}$ by $4 \mathrm{~m}$ while the subplots measured $2.5 \mathrm{~m}$ by $4 \mathrm{~m}$ with a $1 \mathrm{~m}$ buffer zone between the subplots and $1 \mathrm{~m}$ separating the main plots, $1.5 \mathrm{~m}$ separated the replicates from one another. The liming materials were applied seven days before planting at the equivalent of $2 \mathrm{~kg}$ for 2 tonnes per hectare, $4 \mathrm{~kg}$ for 4 tonnes per hectare, $6 \mathrm{~kg}$ for 6 tonnes per hectare and $8 \mathrm{~kg}$ for 8 tonnes per hectare. The applied liming materials were incorporated into the top $15 \mathrm{~cm}$ soil.

The test crop was maize Oba super yellow 11 obtained from the National Seed Services, Umudike. The planting was carried out in the month of June for 2005 and May for 2006 planting seasons. The maize was planted at a spacing of $0.50 \mathrm{~m}$ between and $0.50 \mathrm{~m}$ within rows at both sides. Three seeds were sown per hole and later thinned to one seedling per stand at 14 days after planting. Lost stands were replaced and weeding was done once manually. Plant parameters measured were plant height at 8 weeks after planting, stem diameter, stover weight and maize grain yield. Standard laboratory procedures were employed for the analyses of soil $\mathrm{pH}$, exchangeable acidity, exchangeable aluminum and exchangeable hydrogen, which were used for the correlation study.

All data generated from experiments 1 and 2 were subjected to analysis of variance (ANOVA) for split plot in RCBD using the MSTATC software package while the means were separated using the Fisher's Least Significant difference (LSD). Linear correlation analysis was done using GENSTAT package.

\section{RESULTS}

Effect of rates of liming materials on nutrient concentration in plants at the end of the greenhouse experiment

The results obtained at the end of the experiment showed that the application 6 tonnes per hectare of cocoa pod husk ash significantly increased the concentration of nitrogen while 


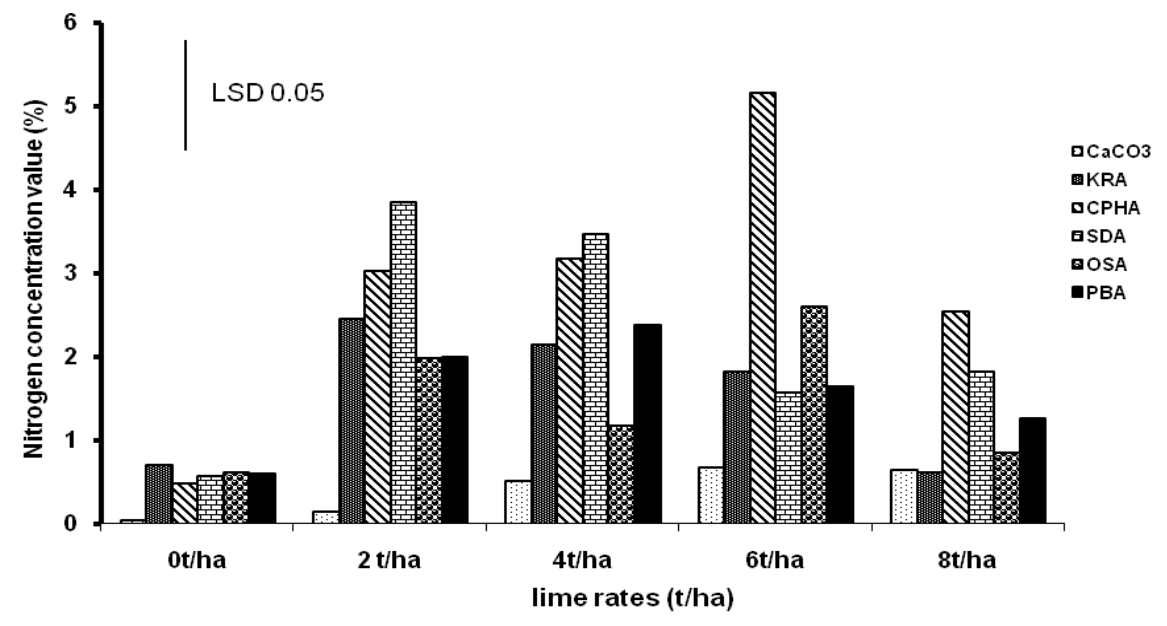

Fig 1: The effect of the liming materials and rates on nitrogen concentration on maize plant at the end of the pot experiment. (Vertical bar represents LSD at 0.05 )

the control gave the lowest concentration of nitrogen in the maize plant as shown in Fig 1.

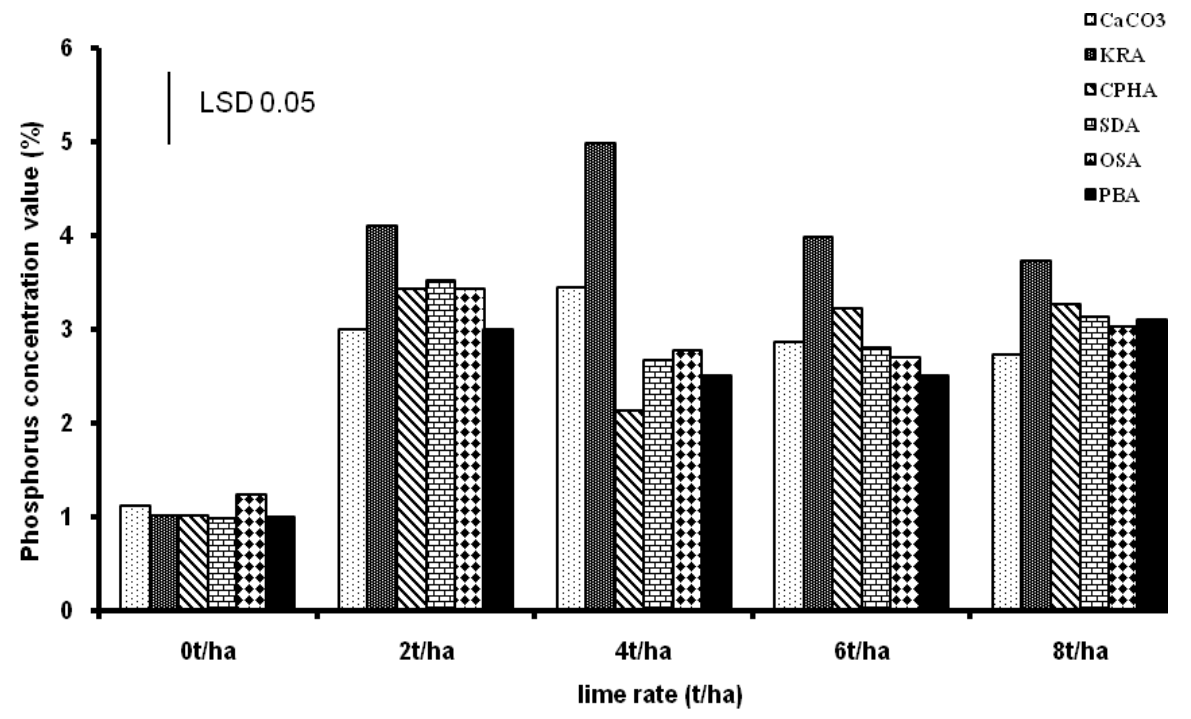

Fig 2: The effect of the liming materials and rates on phosphorus concentration on maize plant at the end of the pot experiment. (Vertical bar represents LSD at 0.05 )

The interaction effect of the liming materials and rates on phosphorus concentration in the maize crop at the end of the pot experiment is shown in Fig 2. Four tonnes per hectare of kitchen residue ash significantly $(\mathrm{P}<0.05)$ gave higher phosphorus concentration in the plant.

The application of 4 tonnes per hectare of cocoa pod husk ash significantly $(\mathrm{P}<0.05)$ increased the potassium concentration in maize plant as presented in Fig 3.

The effect of the liming material on calcium concentration on maize plant is shown in Fig 4.
The result indicated that the application of 2, 4, 6 and 8 tonnes per hectare of oyster shell ash gave the highest value of calcium concentration compared to the other treatments.

The application of the liming materials decreased the concentration of iron and manganese significantly $(\mathrm{P}<0.05)$ over the control as shown in Figs 5 and 6. Calcium carbonate applied at the rates of 2, 4, 6 and 8 tonnes per hectare significantly reduced the concentration of the iron and manganese in the plant. 
Onwuka, M. I. and Osodeke, V.E.

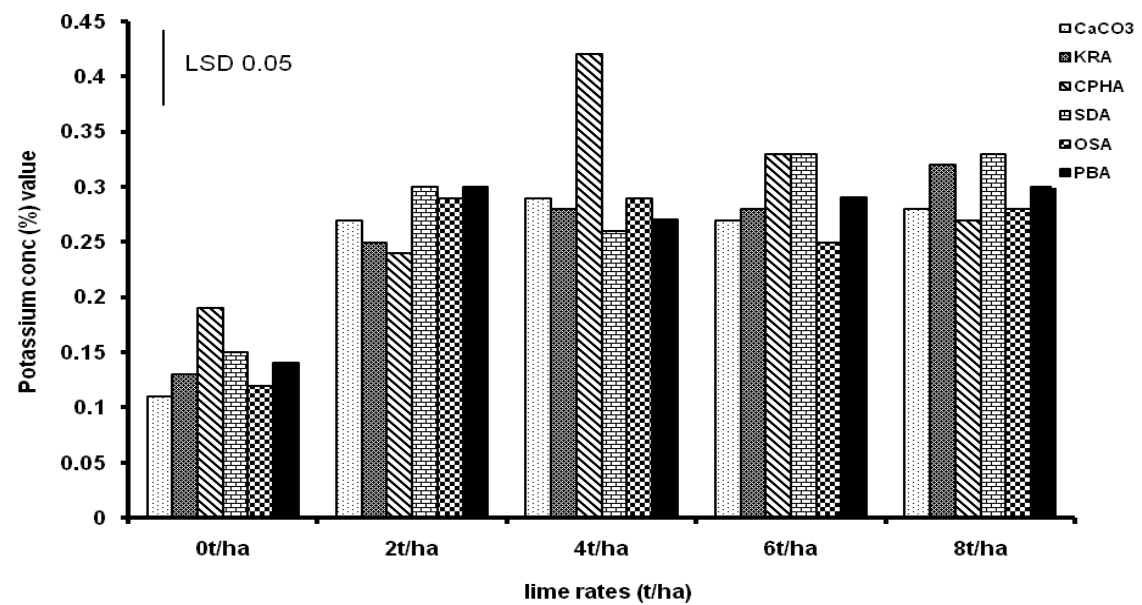
Fig 3: The effect of the liming materials and rates on potassium concentration on
maize plant at the end of the pot experiment. (Vertical bar represents LSD at 0.05 )

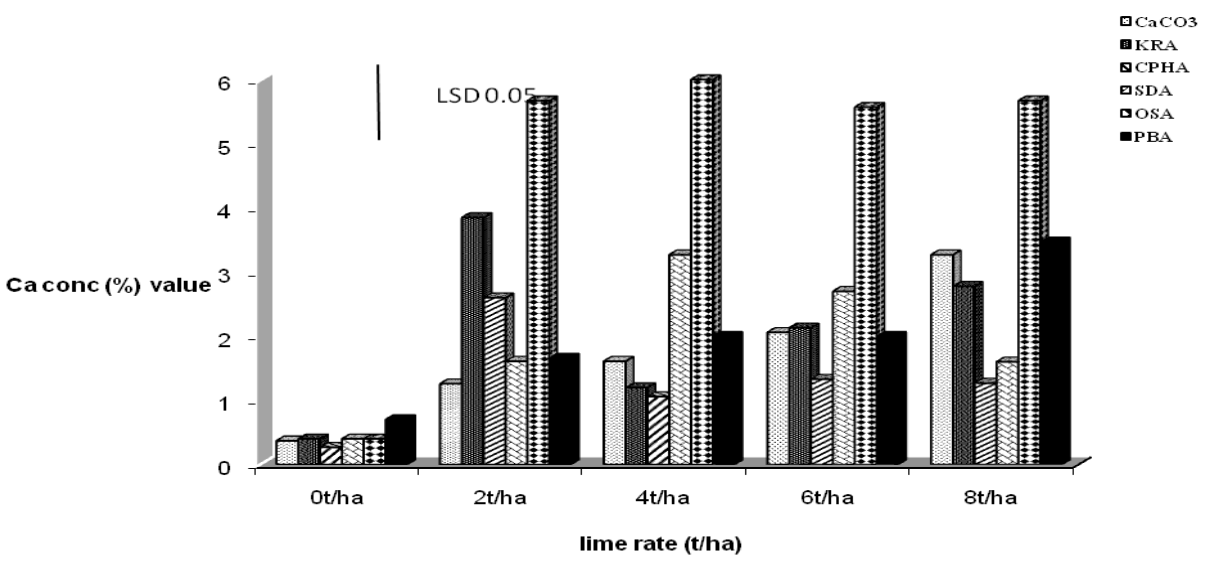

Fig 4: The effect of the liming materials and rates on calcium concentration on maize plant at the end of the pot experiment. (Vertical bar represents LSD at 0.05 ) 
Effects of Agricultural Wastes Ash on Nutrients Concentration and Yield of Maize

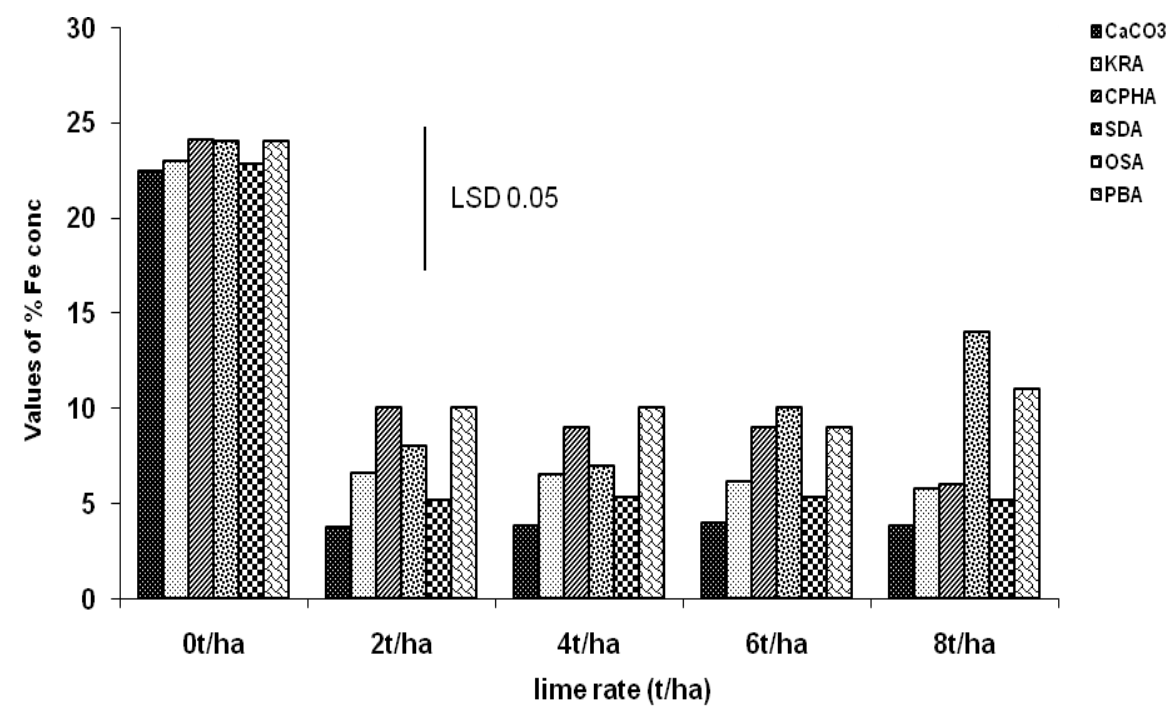

Fig 5: Effect of the liming materials and rates on iron concentration on maize plant at the end of the pot experiment. (Vertical bar represents LSD at 0.05 )

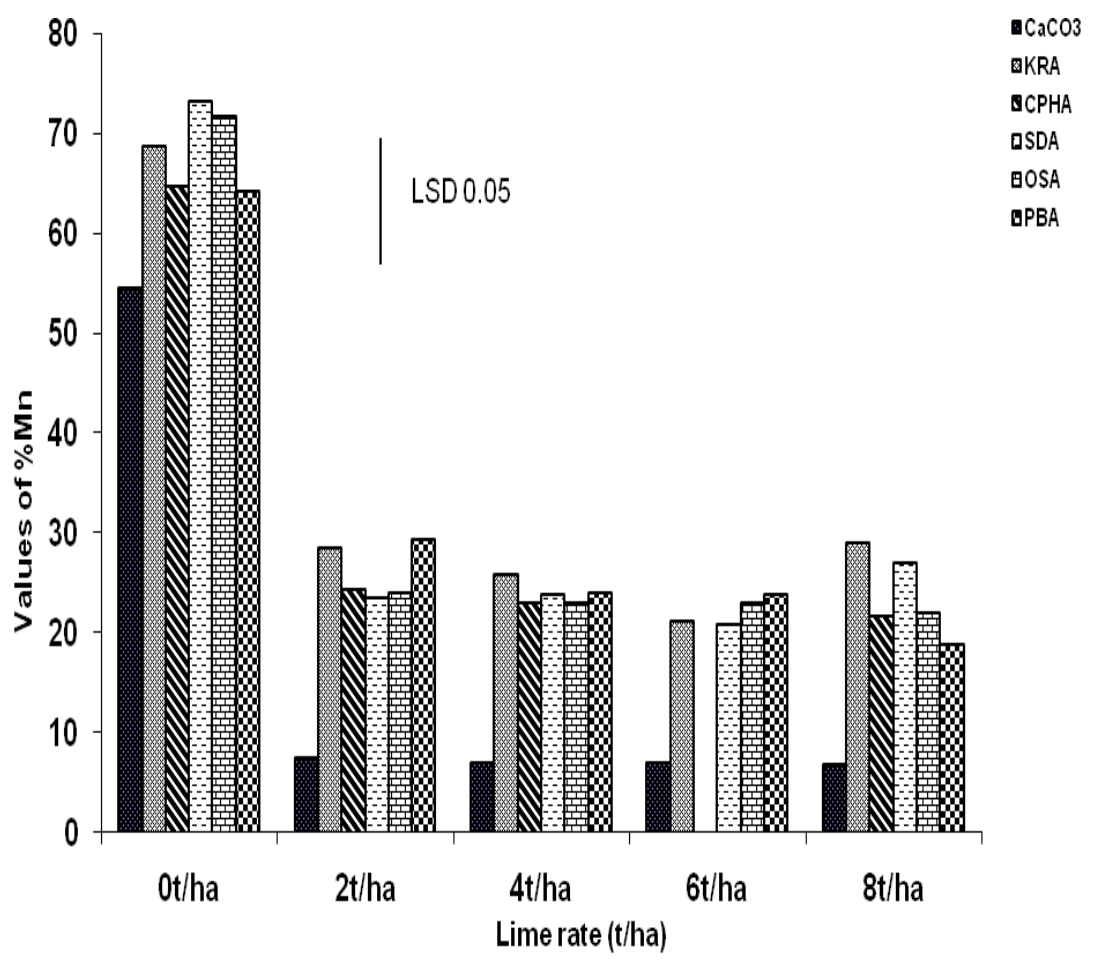

Fig 6: Effect of the liming materials and rates on manganese concentration on maize plant at the end of the pot experiment. (Vertical bar represents LSD at 0.05) 
Effect of liming materials and rates on maize growth parameters and yield at the end of field trails 2005 and 2006 planting seasons

The effect of liming materials and rate on maize plant at 8 week after planting in 2005 and 2006 planting seasons is shown in Table 1. The result obtained showed that in 2005 planting season, there were no significant differences among the liming materials. For the rates, $6 \mathrm{t} / \mathrm{ha}$ gave the highest significant value of $171.78 \mathrm{~cm}$. For the interaction between liming materials and rates, 6 $\mathrm{t} / \mathrm{ha}$ of cocoa pod husk ash significantly $(\mathrm{P}<0.05)$ increased the plant height compare to the other treatments. In 2006 planting season, there were no significant differences among the liming materials and the rates. The application of $6 \mathrm{t} / \mathrm{ha}$ of cocoa pod husk ash significantly $(\mathrm{P}<0.05)$ increased the plant height compare to the other treatments.

In 2005, the result (Table 2) obtained showed that there were no significant differences among the liming materials, rates and treatments interactions for the stem diameter. In 2006, 8 $\mathrm{t} /$ ha showed a significant $(\mathrm{P}<0.05)$ increase among the rates while the interaction of $8 \mathrm{t} / \mathrm{ha}$ of kitchen residual ash significantly $(\mathrm{P}<0.05)$ increased the stem diameter compared to the other interactions.

Table 1: Effect of the liming materials and rates on plant heights (cm) in 2005 and 2006 planting seasons

\begin{tabular}{|c|c|c|c|c|c|c|c|c|c|c|c|c|}
\hline \multicolumn{6}{|c|}{$\begin{array}{c}2005 \text { planting season } \\
\text { Lime rate }(\mathrm{t} / \mathrm{ha})\end{array}$} & \multicolumn{7}{|c|}{$\begin{array}{r}2006 \text { planting season } \\
\text { Lime rate }(\mathrm{t} / \mathrm{ha})\end{array}$} \\
\hline $\begin{array}{l}\text { Liming } \\
\text { Material }\end{array}$ & 0 & 2 & 4 & 6 & 8 & mean & 0 & 2 & 4 & 6 & 8 & mean \\
\hline $\mathrm{CaCO}_{3}$ & 121.00 & 168.80 & 168.70 & 167.20 & 174.10 & 159.69 & 155.10 & 184.10 & 188.60 & 192.10 & 198.50 & 185.69 \\
\hline KRA & 137.80 & 179.80 & 173.10 & 175.50 & 174.50 & 168.14 & 154.20 & 181.30 & 181.10 & 189.00 & 171.10 & 179.34 \\
\hline CPHA & 134.00 & 159.40 & 164.00 & 189.89 & 180.80 & 162.00 & 155.80 & 180.20 & 185.50 & 230.20 & 198.30 & 189.20 \\
\hline OSA & 145.40 & 163.10 & 168.80 & 168.10 & 166.90 & 162.22 & 160.40 & 203.90 & 185.20 & 211.30 & 180.50 & 188.26 \\
\hline PBA & 140.30 & 157.10 & 169.00 & 170.40 & 163.70 & 160.10 & 163.00 & 187.90 & 197.20 & 197.00 & 191.00 & 189.22 \\
\hline Mean & 137.10 & 165.85 & 167.35 & 171.78 & 171.42 & & 166.30 & 188.67 & 189.70 & 192.00 & 186.20 & \\
\hline & $\begin{array}{l}\text { Lsd }(0.05 \\
\text { Lsd }(0.05 \\
\text { Lsd }(0.05 \\
2.67\end{array}$ & $\begin{array}{l}\text { or liming } \\
\text { or lime r } \\
\text { or liming }\end{array}$ & $\begin{array}{l}\text { terials }= \\
=18.20 \\
\text { terial } \mathrm{x} 1\end{array}$ & $\begin{array}{l}\text { not signi } \\
\text { rate }=18\end{array}$ & & & $\begin{array}{c}\mathrm{Ls} \\
\mathrm{L} \\
\mathrm{L}\end{array}$ & $\begin{array}{l}(0.05) \text { fo } \\
(0.05) \mathrm{f} \\
(0.05) \mathrm{f}\end{array}$ & $\begin{array}{l}\text { ming } \mathrm{ma} \\
\text { lime rate } \\
\text { liming } \mathrm{m}\end{array}$ & $\begin{array}{l}\text { cial =ns } \\
\text { is } \\
\text { rials x li }\end{array}$ & rate $=$ & \\
\hline
\end{tabular}

Table 2: Effect of the liming materials and rates on stem diameter $(\mathrm{cm})$ in 2005 and 2006 planting seasons

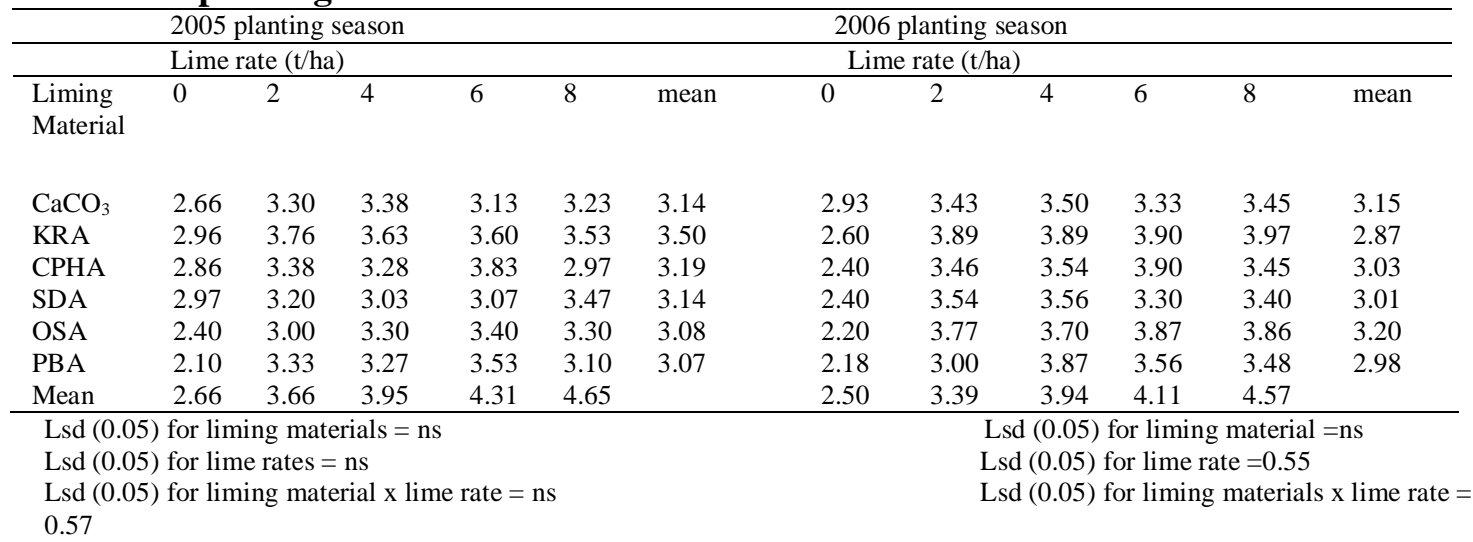


The effect of the treatment on stover weight is shown in Table 3, the result showed that there were no significant differences among the liming materials, lime rates and liming materials and rates interactions in 2005. In 2006, the result obtained showed that lime rate of $8 \mathrm{t} / \mathrm{ha}$ significantly $(\mathrm{P}<0.05)$ increased the stover weight while the interaction of cocoa pod husk ash at 6 t/ha significantly $(\mathrm{P}<0.05)$ increased the stover weight.

The effect of the liming materials on maize grain yield in the field experiment is shown in Fig 7. In 2005 and 2006 planting season, 8 t/ha and 6 $\mathrm{t} / \mathrm{ha}$ of kitchen residue ash significantly $(\mathrm{P}<0.05)$ increased maize grain yields respectively

Table 3: Effect of the liming materials and rates on stover weight $(\mathrm{kg} / \mathrm{plot})$ in 2005 and 2006 planting seasons

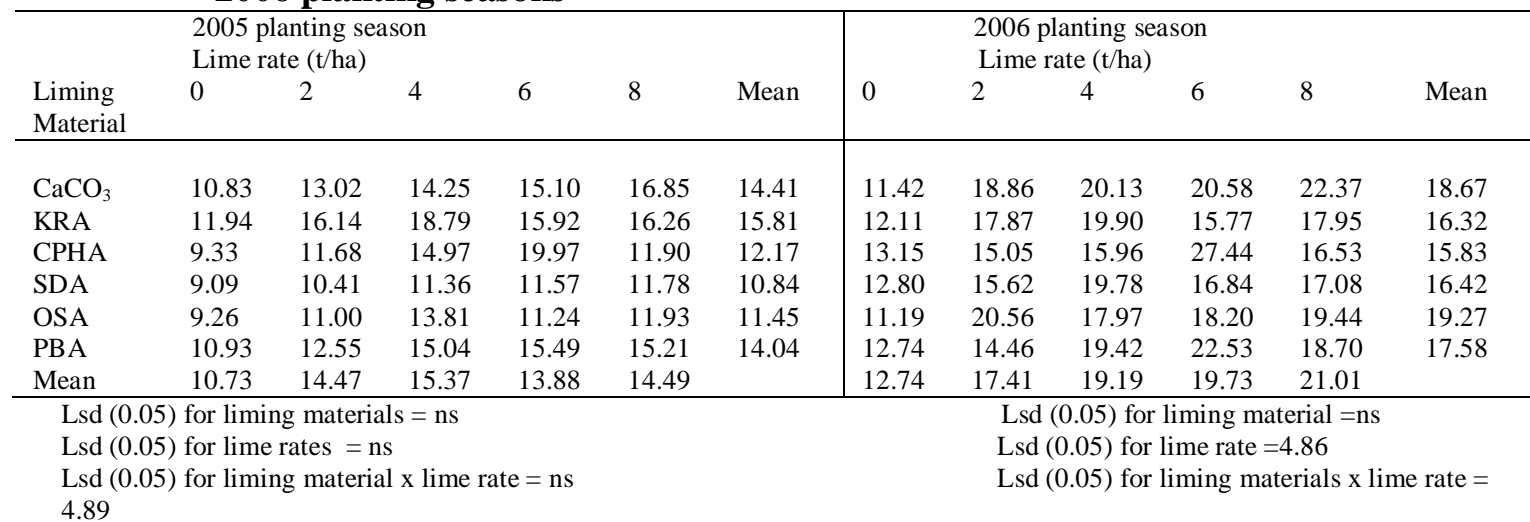

Table 4: Correlation between acidic indices and plant nutrient concentration.

\begin{tabular}{lccll} 
Nutrient & $\leftarrow$ & & \\
Concentration & $\mathrm{pH}\left(\mathrm{H}_{2} \mathrm{O}\right)$ & Ex. Acidity & Ex Hydrogen & Ex. Aluminum \\
$\mathrm{Fe}$ & $-061^{* *}$ & $071^{* * *}$ & $0.60^{* * *}$ & $0.63^{* * *}$ \\
$\mathrm{Mn}$ & $-0.62^{* *}$ & $0.81^{* * *}$ & $0.46^{* *}$ & $0.83^{* *}$ \\
$\mathrm{P}$ & $0.44^{*}$ & $-0.65^{* * *}$ & $-0.25^{\mathrm{ns}}$ & $-0.76^{* * *}$ \\
$\mathrm{Ca}$ & $0.31^{\mathrm{ns}}$ & $-0.53^{* * *}$ & $-0.43^{*}$ & $-0.43^{*}$ \\
$\mathrm{Mg}$ & $0.33^{\mathrm{ns}}$ & $-0.48^{* *}$ & $-0.40^{*}$ & $-0.37^{*}$ \\
$\mathrm{~K}$ & & $-0.46^{* *}$ & $-0.17^{\mathrm{ns}}$ & $-0.53^{* *}$ \\
\hline$* * *$ & $=$ & Significant at $\mathrm{P}<0.00$ & & \\
$* *$ & $=$ & Significant at $\mathrm{P}<001$ & & \\
$*$ & $=$ & Significant at $\mathrm{P}<0.05$ & & \\
$\mathrm{Ns}$ & $=$ & Not significant & &
\end{tabular}


Onwuka, M. I. and Osodeke, V.E.

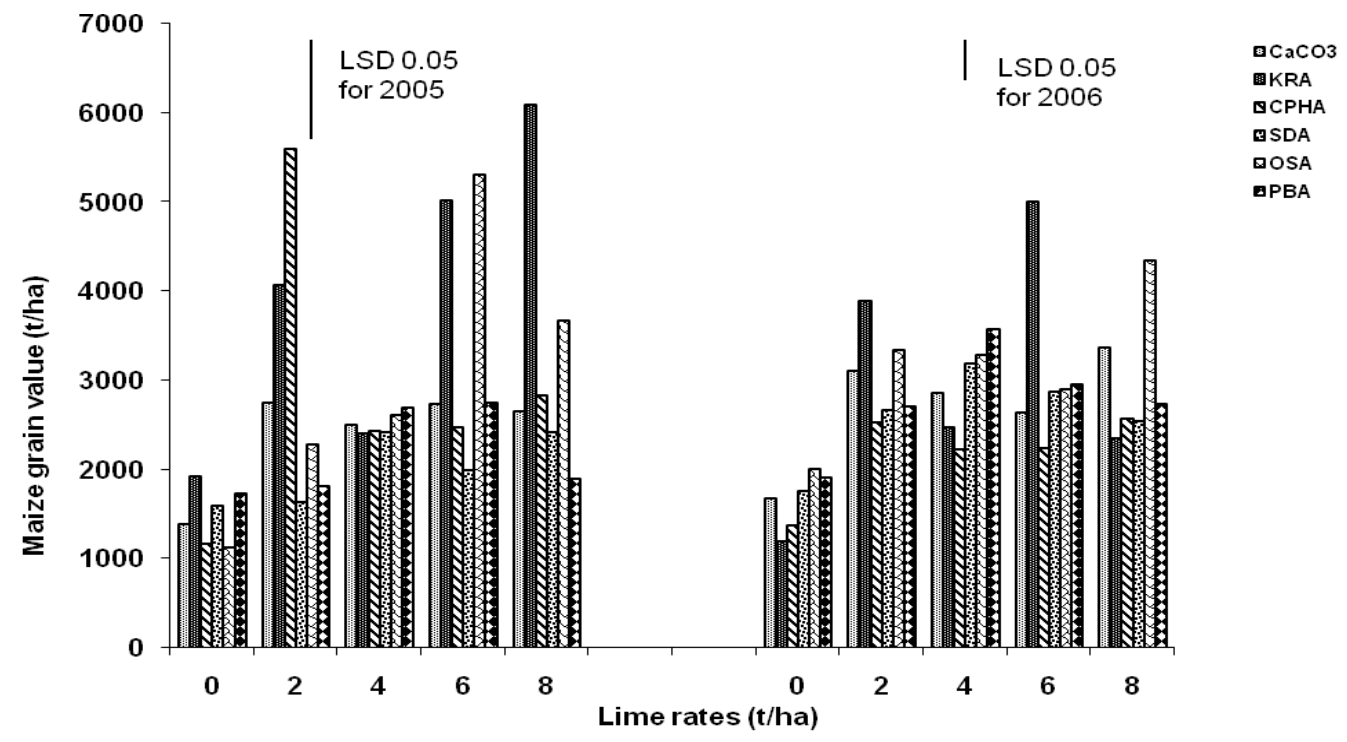

Fig 7: Effect of liming material and rate on maize grain yield at the end of 2005 and 2006 planting season. (Vertical bars represent LSD at 0.05)

\section{Correlation between acidic indices and plant} nutrient concentrations.

The correction study between acidic indices and plant nutrient concentration is shown in Table 4. The soil $\mathrm{pH}$ correlated negatively and significantly $(\mathrm{P}<0.01)$ with iron and manganese concentration in the plant. It also correlated positively and significantly $(\mathrm{P}<0.05)$ with phosphorus but had no significant relationship with calcium. Exchangeable acidity correlated positively and significantly $(\mathrm{P}<0.001)$ with iron and manganese, while it correlated negatively and significantly with phosphorus, calcium and potassium. Exchangeable hydrogen positively correlated with $\mathrm{Fe}$ and $\mathrm{Mn}$ concentration and these relationships were significant $(\mathrm{P}<0.001$ and $\mathrm{P}<0.01)$ respectively. Exchangeable hydrogen correlated negatively with phosphorus, calcium and potassium.

. Exchangeable aluminum correlated positively and significantly with $\mathrm{Fe}$ and $\mathrm{Mn}$ $(\mathrm{P}<0.00$ and $\mathrm{P}<0.01$ respectively). Exchangeable aluminum also correlated negatively with $\mathrm{P}, \mathrm{Ca}$ and $\mathrm{K}$.

\section{DISSCUSSION}

The increase in the concentration of nutrients in the soils could be attributed to the ash application which had been found to have a high liming effect and is able to increased soil $\mathrm{pH}$ (Odedina, 2003; Onwuka et al.; 2007). When the soil $\mathrm{pH}$ is increased the concentration of the nutrients in the maize will also increased as shown by the correlation study. This is because the increase in $\mathrm{pH}$ would create a better environment for the effective and efficient functioning of the microorganisms especially bacteria. These bacteria help in the decomposing of the organic materials, thereby releasing the nutrients for plants uptake. According to Dee et al (2003) and Boath and Arnebrant (1994), at high $\mathrm{pH}$ of 6-8 the microbial activities and rates in the soil are increased. Increased nitrogen concentration by the application of $6 \mathrm{t} / \mathrm{ha}$ of cocoa pod husk ash also led to an increase in plant height, stem diameter and stover weight. This shows that the nitrogen take up by the maize plant were translated into vegetative growth. The application of the ash increased the phosphorus concentration. This was probably because as the soil $\mathrm{pH}$ increased, phosphorus which had been fixed by aluminum at $\mathrm{pH}$ of below 5.5 became available for plant uptake (Verma and Singh 1996 and Osodeke 2000). This is supported clearly by the data in Table 2, where exchangeable aluminum had a highly significant and negative correlation with phosphorus concentration, meaning that when the $\mathrm{pH}$ is reduced, $\mathrm{P}$ will be least available. Potassium and calcium concentrations were increased by the application of the ash. These results agree with the findings of Comin et al. (2006) and Owolabi et al. (2003) who also observed that application of lime and ash increased the uptake of potassium and calcium in plants. The increase in the nutrient concentration of maize and other crops due to the application of ash had been reported by many researchers such as Ayeni, et al, (2008), Moyin Jesu, (2007), Awodun et al., (2007) and 
Effects of Agricultural Wastes Ash on Nutrients Concentration and Yield of Maize

Nottidge., ( 2007, ), they observed that plots that received ash had increased uptake of $\mathrm{N}, \mathrm{P}$, $\mathrm{K}, \mathrm{Ca}$ and $\mathrm{Mg}$.

The positive correlation relationship between exchangeable acidity and the concentration of iron and manganese indicates that the more acidic the soil is, the more the concentration of these nutrients will be in the plants. As liming increases the soil $\mathrm{pH}$, there will be a reduction in the uptake of Fe and $\mathrm{Mn}$ whose availability in the soil is affected by the soil $\mathrm{pH}$.

\section{CONCLUSION}

Cocoa pod husk ash, oyster shell ash, kitchen residue ash, palm bunch ash and saw dust ash could serve as local alternatives to the expensive conventional liming materials. On the average, it requires 6t/ha of cocoa pod husk ash, 4t/ha of oyster shell, 4t/ha of cocoa pod husk ash, 4t/ha of kitchen residue ash, to increase the concentration of nitrogen, calcium, potassium and phosphorus in maize plant. Application of cocoa pod husk ash at $6 \mathrm{t} / \mathrm{ha}$ or $8 \mathrm{t} / \mathrm{ha}$ may be needed to increase the maize grain yield.

\section{ACKNOWLEDGEMENTS}

The authors acknowledge the Education Trust Fund and Michael Okpara University of Agriculture Umudike, Nigeria, for funding part of the first author's PhD research.

\section{REFERENCE}

Ahn, P. M., (1993). Tropical soils and fertilizer. Published by Longman Group UK Limited pp $136-137$

Akinbola, G. E., Omueti, J. A. I, Adigun M. O. and Ajayi O.R. ( 2009). Agronomic and Economic Evaluation of OrganoMineral Fertilizer for Maize Production on an Alfisol in Southwestern Nigeria. Proceedings of the $33^{\text {rd }}$ Annual Conference of the Soil Science Society of Nigeria. Held at Ado- Ekiti from March 9-13. pp 130-137

Association of Analytical Chemists (1984). Official methods of analysis $14^{\text {th }}$ AOAC. Arlington VA.

Aswalam, D.O. and Onyegbule, U. (2009). Effects of some local liming materials and organic manure on some soil chemical properties and growth of maize. Nigerian Journal of Soil Science 19; 2 : 71-76

Awodun, M.A., S.O. Ojeniyi, A. Adesoye and S.A. Odedina, (2007). Effect of oil palm bunch refuse ash on soil and plant nutrient composition and yield of maize. American-Eurasian Journal of Sustainable Agriculture, 1(1): 50-54.
Ayeni, L.S., Adetunji, M.T., Ojeniyi, S.O., Ewulo, B.S. and Adeyemo, A.J (2008). Comparative and Cumulative Effect of Cocoa Pod Husk Ash and Poultry Manure on Soil and Maize Nutrient Contents and Yield, Am.-Eurasian J. Sustain. Agric., 2(1): 92-97

Boath, E and Araebrant, K (1994). Growth rate and response of bacterial communities to $\mathrm{pH}$ in limed and ash treated forest soils. Biology and Biochem 26: 9951001

Comin J. J., Barloy, J. Hallaire, V. Zanette, F, and Miller, P. R. M. (2006). Effects of Aluminum on the adventitious root system, aerial biomass and grain yield of maize Grown in the field and in a rhizotron. Experimental Agriculture 42(3): 351-366.

Dee, B.M., Hayness, R.J. and Graham, M.H., (2003). Changes in Soil acidity and the size and activity of the microbial biomass in response to the addition of sugar mill wastes, Biology and Fertility of Soils 32:47-54

Eleweanya, N.P, Uguru, M.I, Eneobong, E.E and Okocha, P.I. (2005). Correlation and path coefficient analysis off grain field related characters in maize (Zea mays L) under Umudike conditions of South Eastern Nigeria. Agro-science Journal of Agriculture, Food, Environment and Extension, vol 4 (1); 24-28

Lee. C.H, Lee H, Lee Y.B, Chang, H.H, Ali, M.A. Min, W., Kim S and Kim, P.J (2007) Increase of available phosphorus by fly-ash application in paddy soil. Common in Soil Science and plants. Analysis 38:1551-1562

Moyin Jesu, E.I., (2007). Use of plant residues for improving soil fertility pod nutrients root growth and pod weight of okra (Abelmoschus esculentum L.). Bioresource Technology 98: 20572064.

Nottidge, D.O., S.O. Ojeniyi and D.O. Asawalam, (2007). Effect of different levels of wood ash on nutrient contents of maize and grain yield in an acid ultisol of Southeast Nigeria. Nigerian Journal of Soil Science, 17: 98-103.

Nwite, J.C., Obalum, S.E., Igwe, C.A. and Wakatsuki, .T. (2011), Properties and potentials of selected ash sources for improving soil condition and sawah rice yields in a degraded Inland valley in Southeastern Nigeria. World Journal of Agricultural Sciences 7 (3) : 304-310

Nwosu, P. O and Chukwu, G.O. (2009). Liming potentials of Leguminous Species on a 
Haplic Acrisol in Southeastern Nigeria. Proceedings of the $33^{\text {rd }}$ Annual Conference of the Soil Science Socitey of Nigeria. Held at Ado- Ekiti from March 9-13. pp 172-178

Odedina, S. A., Odedina, J. N., Ayeni, S.O., Arowojolu, S.A., Adeyeye, S. D. and Ojenniyi, S.O. (2003). Effect of types of ash on soil fertility nutrient availability and yield of tomato and pepper. Nigeria Journal of Soil Sciences 13: 61-67

Onwuka, M.I. Osodeke, V.E. and Okolo, N. (2007). Amelioration of Soil Acidity using

Cocoa pod husk ash for maize production in Umudike area of Southeastern Nigeria. Tropical and Subtropical Agroecosysterm 7: 41-45

Osodeke, V. E. (2000) Potentials of Biofertilizers for soil fertility management in Southeastern Nigeria. Food and Fiber Production in Nigeria 277-282
Owolabi, O., Adeleye, A., Oladejo, B.T.and Ojeniyi, S.O., (2003) Effect of wood ash on soil fertility and crop yield in south west Nigeria. Nigeria Journal of Soil Science, 13:55- 60.

Sanchez, P. A., Villachia, J.H. and Brandy, D. E (1983). Soil fertility dynamics after clearing a Tropical rainforest in Peru. Soil Sci. Am. Journ. 47; 1171-1178

Verma, T. S. and Singh, S. (1996). Effect of Lime and Gypsum on different forms of soil aluminum and acidity and crop yields in acid Alfisol of Himachal Pradesh. Journal of the Indian Society of Soil Science. Vol 44. no 3 pp417421. 